\title{
地域事象の計量分析における諸問題
}

\author{
奥野隆史 \\ SOME PROBLEMS IN QUANTITATIVE ANALYSIS OF \\ REGIONAL PHENOMENA
}

\section{Takashi Okuno}

\section{1. まえがき}

地域事象の最大の特徴はそれが 2 次元的（=空間的） な特性を持っていることである.したがって, この事象 の計量的な処理にさいしてはこの特性を考虑したアプ ローチ抢よび既存の計量的分析法の適用の工夫が当然の ことながら必要とされる。ここでは, 地域事象を専門的 かつ計量的に研究し, 地域理論の構築を目ざす計量地理 学の分野で行われてきた，それらの工夫およびその問題 点を整理し，基本的なものを述べることとする.

\section{2. 点的地域事象の分布パターンの分析}

地域事象は研究対象地域のスケールいかんによって 点・線・面のいずれかにみなし得る。例えば，関東地方 の諸都市を見るとき，その地方を小スケール地図の意味 で取れば，その諸都市は点的な事象に，大スケール地図 で取ればそれは面的な事象となろう。この意味での点的 事象の空間的な分布パターンの分析は, 地域研究に括け るもっとも重要な課題の一つであり, この分布特徴を計 量的にとらえるこころみは点分布パターン分析といわ れ, 計量地理学の中心課題の一つとなっている. それ は, この分析を通じて点的事象の立地過程や分布システ ムの解明が可能となるからである.

\section{1 地域的積率}

点分布パターン分析の方法は二つに大別できる.一つ は, 通常の諸事象の 1 次元分布に関する測度として定義 されている平均や分散などに対応した， 2 次元分布につ いての記述統計量を誘導し, それによって任意の地域の 点的事象の分布パターンを計測・記述するこころみであ

* 筑波大学地球科学系 (Inst. of Geoscience, Univ. of Tsukuba)
る.このこころみは地域的積率 (areal moment) の問題 といわれ，Bachi (1963) やNeft (1966) などによって 研究されている。そ机らによると, ある地域に叔ける任 意点 $j$ に関する $n$ 次積率 $M_{n}$ は次式によって与えられ ている.

$$
M_{n}=\left(\sum_{i=1}^{N} p_{i} r_{i j}{ }^{n}\right) / P
$$

ここでの $N$ は地域に括沙る点の数, $p_{i}$ は点 $i$ に対す る比重, $r_{i j}$ は点 $i$ から点 $i$ までの距離, $P=\sum_{i=1}^{N} p_{i}$. 1 次元分布に和ける平均に相当する平均中心 (mean center) は $\left(M_{2}\right)^{1 / 2}$ が最小となる点 $i$ である. $p_{i}=1$ の 場合この中心の座標は, 任意の原点を持つ直交座標系の 第 1 象限に諸点が分布するとすれば, $M_{2}=\sum_{i=1}^{N}\left[\left(x_{i}-\right.\right.$ $\left.\left.x_{j}\right)^{2}+\left(y_{i}-y_{j}\right)^{2}\right]$ を $x_{j}$ と $y_{j}$ に関して微分することに よって容易に一意的に次のように求め得る.

$$
x_{j}=\bar{x}=\left(\sum_{i=1}^{N} x_{i}\right) / N, \quad y_{j}=\bar{y}=\left(\sum_{i=1}^{N} y_{i}\right) / N
$$

各点に対する比重 $p_{i}$ が人口である場合, 平均中心は人 口論でしばしば展開されている人口重心となる。

中央值に対応する中央中心は $M_{1}$ が最小となる点と定 義されるが，この座標を代数的に見出すことはむずかし く, Porter (1963) が指摘しているようにその解は一意 的に定まらない1). この点に打いて注目されるのは, Seymour (1965) による方眼被覆 (grid overlapping) 法 といわれる一種の反復探索法である.この方法は次の 5

1）このことは，簡単な仮説事例を提示することによ ってすでに Hayford（1902）が示唆している. 


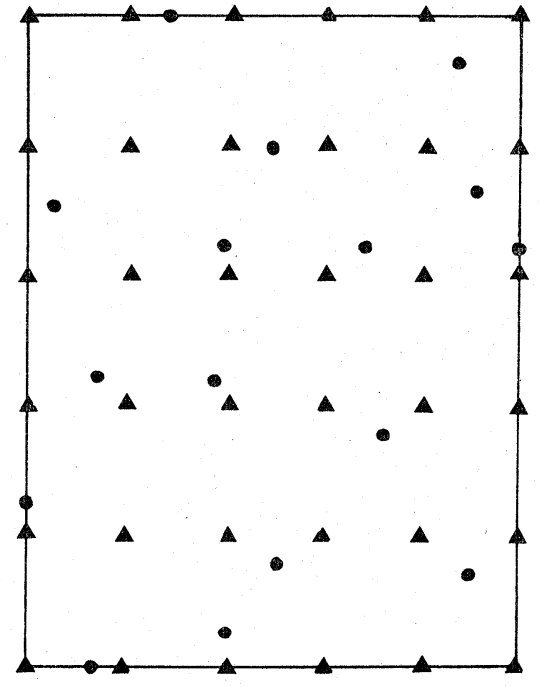

図1 方眼被覆法（第1段階）

黒丸はデータ点, 三角は方格点

操作をともなっている. (1)縦・横ともに同数軸を持つ方 眼を対象地域にかぶせる。この場合, 方眼の境はその地 域に分布する最端 4 点の位置によって決まる. (2)方眼内 の方格点 $\left(x_{0}, y_{0}\right)$ からデータ点としての各点までの平 方距離の和の平方根, つまり,

$$
\left\{\sum_{i=1}^{N}\left[\left(x_{0}-x_{i}\right)^{2}+\left(y_{0}-y_{i}\right)^{2}\right]\right\}^{1 / 2}
$$

を求める. (3)この結果より, 最小值を取る方格点を一つ だけ抽出する.これの座標を $\left(x_{j}, y_{j}\right)$ としょう. (4)こ の点を中心として, 前の方眼より細かい新しい方眼をか ぶせる.この場合の方眼での縦横両軸の数は前の場合と 同じとする.いらまでもなく前のデータ点の一部分しか 新しい方眼は扮拉わない. そして式 (2.3) の $x_{0}$ と $y_{0}$ を $x_{j}$ と $y_{j}$ に置さ換えたものにもとついて距離計測を行 い, 最小值を取る 1 方格点を抽出する. (5以下同様の作 業を反復する。ここで注意すべきは，このような操作を 過度に反復しても無意味なことであり，いたずらな反復 は「偽りの正確さ」をもたらすだけである。

通常の標準偏差に相当する 2 次元分布における 測度 は, 式 (2.1) の点 $j$ を平均中心とする場合の $\left(M_{2}\right)^{1 / 2}$ であり, $p_{i}=1$ の場合標準距離として知られている.つ まりこの種の距離 $d$ は次式によって与えられる.

$$
d=\left[\left(\sum_{i=1}^{N} r_{i c}\right) / N\right]^{1 / 2}
$$

ここでの $r_{i c}$ は平均中心から点 $i$ までの距離. この測度
は相異なる諸地域の点的事象の分布に関するばらつきに ついての比較に有用であるばかりでなく，1地域をその 分布特徵で区分する場合のそれの有意性を判断するため の指標ともなる. それは, 地域を $k$ 個の小地域に区分 した場合， $d^{2}$ は小地域内平方距離 $d_{w}^{2}$ と小地域間平方 距離 $d_{b}^{2}$ との和に等しいからである.すなわち,

$$
\begin{aligned}
d^{2} & =d_{w}^{2}+d_{b}^{2}=\left\{\sum_{j}^{k} \sum_{i}^{N_{j}}\left[\left(x_{i j}-\bar{x}_{j}\right)^{2}+\left(y_{i j}-\bar{y}_{j}\right)^{2}\right]\right\} / N \\
& \left.+\left\{\sum_{j}^{K} N_{j}\left[\bar{x}_{j}-\bar{x}\right)^{2}+\left(\bar{y}_{j}-\bar{y}\right)^{2}\right]\right\} / N
\end{aligned}
$$

である.ここでの $\left(x_{i j}, y_{i j}\right)$ は小地域 $j$ に执ける点 $i$ の座標, $\left(\bar{x}_{j}, \bar{y}_{j}\right)$ はその小地域での 平均中心の 座標, $N_{j}$ はその小地域での点の数.

これらの地域的積率による分析は, いわば相としての 点的事象の分布パターンをいくつかの地域について比較 検討するさいには有効であるが，それがどのよらな形状 であるかについては何らの情報も与えない。この要請に 応ずるのが下述の方格 (quadrat) 法と近隣単位 (nearestneighbor） 法 ${ }^{2}$ であり, それに関連する諸問題が点分布 パターン分析の中心論題となっている.これら 2 万法は いずれも，生物個体またはコロニーの 2 次元分布パター ンの認定法とその存在過程の解明法を問題とした生物生 態学によって提唱されたものであるが, 生物も地表上の 事象なので, 一般的な地域事象についてもそれらを適用 できることは自明といえよう。

\section{2 方 格 法}

この方法は対象地域をいくつかの同面積方格に分割 し, その方格を集計単位としてその中に含まれる点の数 を算えることによって，その数を持つ方格数を度数とす る. そして, 点的事象の分布存在過程から理論的に導か れた確率モデルの与える分布をその度数分布に適合させ ることによって, 点の分布パターンの形状をそのモデル で表現しよらとするものである，適合さるべき確率モデ ルとしては, ポアンン・負の 2 項・ガンマ・正規などの 基本的なモデルのほかにネイマン $\mathrm{A}$ 型・トーマスの 2 重 ポアソン・ポリアニエゲンベルガーなどの特殊なものも 利用されている3).

点の分布パターンの基本的形状としてはランダム型・

2）この方法は隣接性あるいは間隔法とも呼ばれるこ ともある。

3）これら各種の確率モデルの一般型を久野 (1974) が 導き，各種のモデルをそれにもとづいて位置づけ ている。 
集中型・均等型の 3 形状が想定されるが，ランダム型に はポアソン分布が, 集中型には負の 2 項分布が一般に適 合性がいいとされている。ポアソン確率モデル（パラ メータ入の推定值は 1 方格あたりの点の平均密度が用い られる）がランダム型の表現モデルとして採用されるの は, ポアソン分布が 2 項分布 $b\left(x_{i} n, p\right)$ の極限の場 合代成立する確率分布であり, 点的事象の出現確率 $p$ が 極端に小さいこと, 拈よび2 項分布がいわ㠴るベルヌー イの試行について成立する分布であることから容易に理 解できよう。集中型に対して負の 2 項確率モデルが採用 されるのは, 現実的な意味において, 点的事象とみなし 得る人口・工場・都市などが集積の利益を受けて立地 し, それらの 1 個体の一定地域に叔ける出現が他の個体 の出現に伝播的に関係することが多く, その結果として 集中型が形成されること, 他方, 負の 2 項確率モデルは 1 回の試行における事象出現がそれ以後の試行における それに連鎖的に影響を与光る状沉についてのモデルであ ることによる. 負の 2 項確率分布モデルは次式のよらに あらわされる。

$$
P(X=x)=\left(\begin{array}{c}
r+x-1 \\
x
\end{array}\right) p^{r}(1-p)^{x}
$$

しかしこのモデルの適合のさいに問題となるのはパ ラメータ $r$ 㧍よび $p$ の推定である. $r$ が正の整数の場 合は Williamson \& Bretherton (1963) による簡単な推 定法— $\hat{p}=\bar{x} / s^{2}, \hat{r}=\bar{x} \hat{p} /(1-\hat{p})$ (ここでの $\bar{x}$ は 1 方 格あたりの点の平均密度, $s^{2}$ は点の数の分散) 一, $r$ が非整数の場合は Anscomb （1950）が提唱した推定法 が利用される。

均等型に適合されるべき理論的な確率モデルについて は適切なものが開発されていないが，その開発の一過程 として, 点がランダムよりむしろ均等に近い分布を呈す る形状についてのモデルが Dacey（1964a）によって提 示されている. そのモデルの誘導過程を地域問題に沿っ て述べると次のと打りである. $c$ 個の方格より成る地域 に $A$ と $B$ の 2 種の都市群（例塈ばアメリカの郡庁都市 之非郡庁都市）があり，それぞれの個数を $z$ と $m$, 全 体の個数を $n$ とする. どの方格も都市 $\mathrm{A}$ を含导確率 $p$ $(=z / c)$ を等しく有するが, 各方格はその都市を一つし か含まないこと，拈よび都市 $\mathrm{B}$ はランダムに 分布し， 平均密度 $m(=n / c)$ で各方格に含まれることを仮定す る.この仮定のもとで任意の方格が合計して $x$ 個の都 市を持つ確率はどうなるかが Dacey によって提起され た問題なのである：この確率を見出すにさいしては起こ り得る 2 事象を考学る必要がある.その一つはその方格
が都市 $\mathrm{A}$ を含先として合計して $x$ 個の都市を持つ、し たがって B の都市を $(x-1)$ 個持つという事象と, 他 の一つはその方格が $\mathrm{A}$ を含まずに合計 $x$ 個の都市を持 つという事象である. 前者の事象の確率は $p m^{x-1} e^{-m} /$ $(x-1)$ ! であり, 後者の事象のそれは $(1-p) m^{x} e^{-m} / x$ ! なので, 互いに排反的なこれら 2 事象をまとめると求め るべき確率が次のように得られる。

$$
P(X=x)=(1-p) m^{x} e^{-m} / x !+p m^{x-1} e^{-m} /(x-1) !
$$

この確率モデルは Dacey によって修正ポアソンモデル と名づけられて打り, これによって与兄られ分布の平均 は $(m+p)$, 分散は $\left(m+p-p^{2}\right)$ であり, パラメータ $m$ 之 $p$ の推定值は $\hat{m}=\bar{x}-\hat{p}, \hat{p}=\left(\bar{x}-s^{2}\right)^{1 / 2}$ によって与

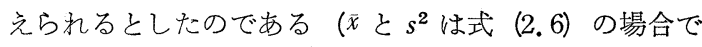
の定義之同様).

以上のような方格法によると，方格の大きさを变える とパラメータが変わり，したがって各モデルが与える理 論的な度数が変わることが容易に理解できよう。この意 味では上述の諸モデルは限定的なものといえる，それゆ 光，一般的なるのの開発が望まれるわけであるが，未解 決のまをである，その点で注目されるのは, 修正ポアソ ンモデルでの 2 パラメータを確率变数とみなし— $m$ は パラメータ $\gamma$ と $\beta$ を有するガンマ確率モデル, $p$ はパ ラメータ $\gamma$ とを有するベータ確率モデルにそれぞれ 従う一, どの上うな状沉にも応じ得る次の上うな確率 分布モデルを誘導した Dacey (1966a) のこころみであ る.

$$
\begin{gathered}
P(X=x)=\frac{\gamma}{\gamma+s} \cdot \frac{(\gamma+x-1) !}{x !(\gamma-1) !}\left(\frac{1}{\beta}\right)^{\gamma}\left(\frac{\beta}{\beta+1}\right)^{\gamma+x} \\
+\frac{r}{\gamma+s} \cdot \frac{(\gamma+x-2) !}{(x-1) !(\gamma-1) !}\left(\frac{1}{\beta}\right)^{\gamma}\left(\frac{\beta}{\beta+1}\right)^{\gamma+x-1}
\end{gathered}
$$

方格法に関する第 2 の問題は点の「分布」と「配列」 との相違である．万格法は実際の点分布パターンについ て同一個数の点を含む方格数を実際的度数とし, 確率モ デルの与光理論的度数分布への適合を骨子とするが， この方法には重要な欠点があるといわれている (Dacey (1966b)). 今, A と B の 2 地域での点の 分布パターン が図2の上らであるとしよう，方格法によると，A と B ともに実際的度数はまったく同じであり, それゆ光に適 合さるべき確率モデルも2地域いずれについても同一に ならざるを得ないわけである。しかし二つのパターンの らち A は集中性を持つが，B 的にも明らかである. 点分布パターンの主目的は 2 次元 

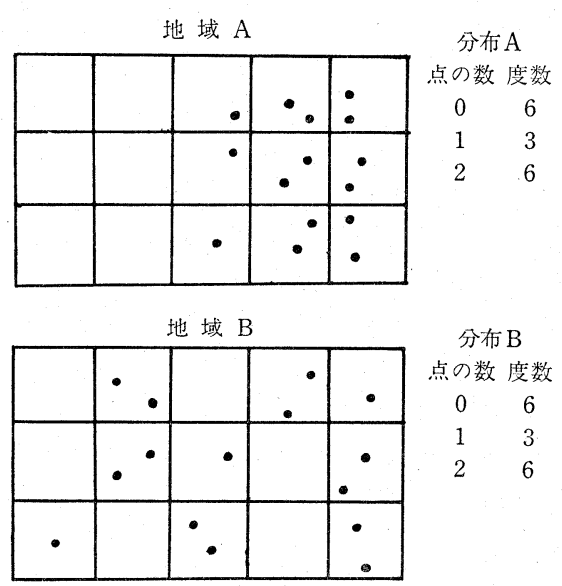

因2 仮説的な点の分布と配列 (Dacey)

分布パターン，換言すれば点の配列パターンの分析にあ るのであって，度数分布で表現されるような 1 次元的な 点の分布パターンにあるのではない. Dacey は 1 地域を 方格で分割した場合一この限りでは方格法といえる 一，この配列パターンがいかなる形状を取るのかの識 別法を $k$-色彩地図の問題としてとらえて研究している. しかし，ランダム型についてのそれしか提示しておら ず，集中と均等の形状についてはまだ見出されていな w.

\section{3 近隣単位法}

方格法に打ける上述の欠点を補らものとして近隣単位 法が挙げられる。これは諸点間の距離の計測を行い, 点 の配列そのものをデータとする方法である。この方法は 一般に順序 (order neighbor) 法と分域 (regional) 法の 二つに大別される. 前者は $N$ 個の点から成る地域にお いて, 任意点 $i$ から他のすべての点までの距離 $\boldsymbol{r}_{i j}(i \neq j)$ を計測し，その值を小さいものから順に並べることから 出発する. 最小の距離から順次 $r_{i 1}, v_{i 2}, \cdots v_{i j}, \cdots, v_{i, N-1}$ とすれば, $r_{i_{1}} \leq r_{i_{2}} \leq \cdots \leq v_{i j} \leq \cdots \leq r_{i, N-1}$ となるわけで ある. 点 $i$ から最小の距離のところにある点およびその 距離 $r_{i 1}$ は, 最近隣単位および最近隣距離と呼ばれる. $j$ 番目の距離のところにある点とその距離 $r_{i j}$ は $j$ 位近 隣単位拉よび $j$ 位近隣距離といわれる。このような計 測が $N$ 個の点それぞれにおいてなされるならば， $N$ 行 $(N-1)$ 列の距離行列 $\left\{r_{i j}\right\}$ がデータとして得られよ ら. そして, 第 1 列の和および第 $j$ 列の和を $N$ で除し た最近隣平均距離と $j$ 位近隣平均距離, つまり,

$$
\bar{r}_{1}=\left(\sum_{i=1}^{N} r_{i_{1}}\right) / N, \quad \bar{r}_{j}=\left(\sum_{i=1}^{N} r_{i j}\right) / N
$$

が求められる.順序法はこれらの平均距離にもとづいて 実際の分布パターンと理論的なそれとを比較することに よって, 前者の形状を識別しようとする方法である.

分域法は, 任意の点 $i$ の周辺平面を図 3 の上らにその 点を中心として $k$ 個のセクターに分割し, 各セクター内

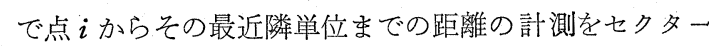
ごとに行い（したがって一つの点 $i$ にいて計測距離の 数は $k$ ，それらを小さい順に並べることから始められ る. その計測值の最小のものから順次 $v_{i_{1}}, r_{i_{2}}, \cdots, r_{i_{k}}$ と すれば, $r_{i_{1}} \leq r_{i_{2}} \leq \cdots \leq r_{i_{k}}$ となるわけで（ $(k=6$ が通例） $N$ 個の点 $i$ についての平均距離は,

$$
\bar{r}_{k}=\left(\sum_{i=1}^{N} r_{i k}\right) / N
$$

で与兄らる。

両方法の利用にさいして注意すべきは, 対象地域それ 自体を一つの有界平面と見るか，あるいは無界平面の一 部と見るかによって被計測点の数が变わることである. かりに $i$ が対象地域の端に位置していて, $j$ 位近隣距離 を計測するとしょう。前者の見方に立てば， $j$ 位近隣単 位はいらまでもなくその地域内に必ず存在すると見るこ とができ, その単位がどこに位置しょうとも距離計測の 対象となる.この場合での距離行列の列数は前述のよう に $(N-1)$ である. しかし，後者の見方によれば， $j$ 位 近隣単位が対象地域を境する境界線の外側に存在する可 能性がある、それにもかかわらずオペレーショナルな意 味では対象地域はその境界線内に限られている。そこ で, 境界線内に存在する $j$ 位近隣単位と識別される点 までの点 $i$ からの距離が, $i$ から境界線むでの距離より 小であるならば，必ずその単位は境界線内に存在し，逆 の場合であれば線外に存在する可能性があるとし, 識別

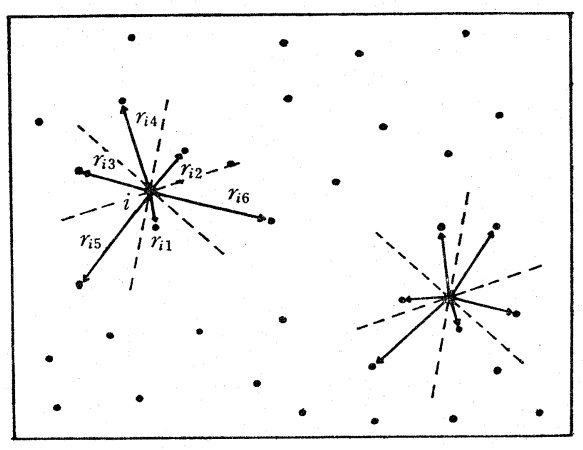

因 3 分域法 ( $k=6$ の場合) 
された $j$ 位近隣単位を計测対象から除くのである．換 言すれば, 点 $i$ をとにする距離を対象地域内のすべて の点について計測せずに, $i$ から境界線までの距離に比 ベて $i$ に近い位置にある点だけに限るわけである，それ ゆえ, 距離行列においてある行についてはその要素数が $(N-1)$ 未満になる場合があるのである. 一般の近隣単 位法による分析では後者の見方に立つ場合が多く, こう した境界に関する制約条件を前提として被計測点が限定 される．順序法と分域法のいずれに打いても，被計測点 の数は $j$ また $k$ が大となるに従って少なくなってい く.この境界に関する制約条件の設定は対象地域に無界 性を与えることによって計測操作が合理的なものとなる 反面，この地域をどう取るか，つまり境界線の画定如何 によって被計測点の数が変動し, それにともなって上述 の諸平均距離も変わるといら問題が生ずる.この問題の ために実際の分布パターンと理論的なそれとの比較が正 しく行い得ない場合が出現する.この問題は境界効果の 問題といわれる.

実際の分布パターンと理論的なとれとの比較におい て,もっとも広範に利用される統計量は Clark \& Evans (1954) による次のものである.

$$
R=\bar{r}_{1} / \bar{r}_{E}
$$

ここでの $\bar{r}_{1}$ は実際の分布パターンについての最近隣平 均距離であり， $\bar{r}_{E}$ は密度 パラメータ入を持つポアソン 確率モデルに従って点がランダムに分布し, 最近隣距離 が正規分布に従らと仮定したとさに導出される最近隣平 均距離の期待值であり， $\bar{r}_{E}=1 / 2 \lambda^{1 / 2}$ で与えられる.こ の統計量は最近隣単位測度と呼ばれ，実際の点の分布パ 多一ンの傾向が集中型のとさは $R<1$, ランダム型のと きは $R=1$, 均等型のとさは $R>1$ となる.もっとも集 中の極端な形状つまり 1 点集中型ならば $R=0$, 他方,

もっとも均等な形状つまり 6 角形状ならば $R=2.1491$ となる. $R$ の検定 $\left(\bar{r}_{1}\right.$ と $\bar{r}_{F}$ の差は有意でないという 帰無仮説の検定）にさいしては，正規分布することが知 られている次の統計量が用いられる.

$$
C=\left(\bar{r}_{1}-\bar{r}_{E}\right) / \sigma_{\vec{r}}
$$

ここでの $\sigma_{\bar{r}} E$ は $\bar{r}_{E}$ の標準誤差であり， $[(4-\pi) /$ $4 \pi N \lambda]^{1 / 2}$ で与えられる.

しかし, Dacey $(1963 \cdot 1964 b)$ はこの測度によるパタ ーン識別は, パターンに関する情報の欠落の危険性を含 んだものとし， $j$ 位近隣距離の利用を主張した。すなわ ち, 点が密度パラメータ入を持つボアソン確率モデルに 従って分布すると仮定した場合, $j$ 位近隣距離は最近隣 距離のときとは異なり，バラメータ $j$ (正の整数) と $\lambda$
をともなら次のよらなガンマ確率モデルに従って分布す るとする。

$$
\left.f\left(r_{i j}\right)=[2 \pi \lambda){ }^{j}{ }_{r_{i j}{ }^{2 j-1}} \exp \left(-\pi \lambda r_{i j}{ }^{2}\right)\right] /(j-1) !
$$

そして, これにもとづいて次のような $j$ 位近隣平均距離 の期待值 $\bar{r}_{j E}$ および実際のパターンと理論的なランダム パターンとの差の有意性の検定統計量を導いた.

$$
\begin{aligned}
& \bar{r}_{j E}=\Gamma[(2 j+1) / 2] /(j-1) ! \lambda^{1 / 2} \\
& \chi^{2}=2 \pi d^{1 / 2} \sum_{i=1}^{N} v_{i j} \quad \phi=2 j N
\end{aligned}
$$

ここでの $d$ は $\lambda$ の推定值. そして $\phi$ がきわめて大きい とき, 式 (2.15) の変換式を次のように提示したのであ る.

$$
Z=\left(2 \chi^{2}\right)^{1 / 2}-(2 \phi-1)^{1 / 2}
$$

$Z$ は標準正規変量. これらの統計量を用いてアイオワ州 の都市分布パターンを分析した結果は表 1 のようであ り,これから自明のように最近隣距離 $(j=1)$ によると ランダム型とはいえないが， $j$ 位近隣距離によるとアイ オワ州の地図から読み取れるよらなランダム型が検証さ れるのである。

表 1. アイオワ州の都市分布パターンに関する諸 統計量 (Dacey)

\begin{tabular}{r|c|c|c|c|c|r}
\hline$j$ & $N$ & $\bar{r}_{j E}$ & $\bar{r}_{j}^{*}$ & $x^{2}$ & $\phi$ & $Z$ \\
\hline 1 & 65 & 0.50 & 0.65 & 200.89 & 130 & 4.00 \\
2 & 64 & 0.75 & 0.84 & 300.63 & 256 & 1.92 \\
3 & 58 & 0.94 & 0.99 & 358.63 & 348 & 0.42 \\
4 & 52 & 1.09 & 1.12 & 423.85 & 416 & 0.29 \\
5 & 47 & 1.23 & 1.24 & 464.48 & 470 & -0.16 \\
6 & 41 & 1.35 & 1.36 & 500.00 & 492 & 0.27 \\
7 & 40 & 1.47 & 1.49 & 567.41 & 560 & 0.24 \\
8 & 39 & 1.57 & 1.60 & 638.48 & 624 & 0.42 \\
9 & 38 & 1.67 & 1.68 & 686.24 & 684 & 0.11 \\
10 & 37 & 1.76 & 1.78 & 741.36 & 750 & 0.05 \\
\hline
\end{tabular}

*ここでの $\bar{r}_{j}$ は密度によって標準化されている.

以上のような近隣単位法は近隣距離にもとづいて実際 の分布パターンと理論的それとの乘離を調べることを骨 子とする. 理論的なものが前述のよらに集中型および均 等型が当然想定されるにもかかわらず, それらとの比較 を行らための 测度や検定統計量はまだ見出されていな い. また境界効果の問題の解決のこころみとして, 無界 平面についての近隣単位法の考察が Dacey $(1965 \mathrm{a} \cdot \mathrm{b} \cdot \mathrm{c})$ によってなされているが，まだ成功していない。 


\section{3. 地域事象の共変動の分析}

地域事象が空間的に共変動する状態についての分析は 地域研究において連綿として論ぜられてきた課題であ る. 古くは諸事象の地図化の結果を比較することによる 分析が一般的であったが, Jones (1930) がアメリカ中 部の農業的属性を計量分析したのを契機として回帰分析 が行われるようになり, それ以来他の多变量解析の諸手 法が適用されてきている.このような共変動の分析にお ける計量化は, 他の地域研究の計量的課題におけるとれ よりも歴史が古いだけに, 地域事象の計量分析固有の問 題が見られる.とりわけ回帰分析の適用についてはとう である. それに対して, Kendall (1939) 以来導入された 主成分分析と因子分析や比較的最近になって適用され始 めた正準相関分析や判別解析などについては深刻な問題 を生じていない，主成分分析々因子分析は，後述するよ らに地域構成の解明といった地域研究に打いてきわめて 重要な課題と密接に関連しているため, 広範に利用され ている.

\section{1 単位地区の問題}

一般に事象域地の共変動の計量分析は行に諸事象を記 述する変数, 列に適当な単位地区（例光ば行政地区）を 取ったデータ行列にもとづいて行われるが, 諸変数につ いて回帰分析をこころみる場合, 単位地区をいくつかま とめた場合回帰係数および相関係数が変わることが知ら れている. 例光ば McCarty et al. (1956) はアメリカ の機械工業の分析に沶いて，単位地区を郡水準にした場 合と州水準にした場合とでは相関係数の相異なることを 見出し, Yule \& Kendall (1950) もイギリスの農業特 性を相関分析したさいに, 相関係数が単位地区をどの水 準にするかによって変動することを見出し，その係数が 単位地区に依存する測度であると指摘した。この問題に 本格的に取り組んだのは Robinson (1956) であり, 彼 はこの問題に対する解決法の一つとして回帰倸数および 相関係数の算定にさいして変数に単位地区の面積を加重 する方法を提示した。 その 1 例として単回帰方程式にお ける回帰係数 $b$ の単位地区数 $N$ についての算定式を挙 げると，次のようなものであった。

$$
\begin{gathered}
b=\left[\sum_{i=1}^{N} A_{i} \sum_{i=1}^{N} A_{i} x_{i} y_{i}-\left(\sum_{i=1}^{N} A_{i} x_{i}\right)\left(\sum_{i=1}^{N} A_{i} y_{i}\right)\right] \\
\\
/\left[\sum_{i=1}^{N} A_{i} \sum_{i=1}^{N} A_{i} x_{i}-\left(\sum_{i=1}^{N} A_{i} x_{i}\right)^{2}\right]
\end{gathered}
$$

ここでの $A_{i}$ は単位地区 $i$ の面積, $x_{i}$ と $y_{i}$ は地区 $i$ の
独立変数之従属变数である.ささらに彼はその後の研究 (Robinson et al.. (1961)) 飞おいて単位地区として 6 角形状区域を用いるのが適切であるとし，一般の行政地 区で集計されるデータをこの地区水準に変換する方法を 提唱した.

Robinson のこれらの研究に対して.Thomas \& Anderson (1965) は, 加重法が一般的な解決法とはならない こと，6角形状区域へ変換する方法については誤差の入 る可能性がきわめて高く, 演算手続きから見て実用的で ないことを指摘した。そして， Robinson が加重法を提 呾したさいに用いた地域についてさまざまな水準の単位 地区を設定し，それぞれにもとづく単回帰係数 $b$ を算出 し，それらの差の有意性検定を行った。その結果はそれ ぞれの係数間に有意差は認められず, 単位地区の相異は 回帰係数に有意な変化をもたらさないと結論した．これ によって単位地区の問題は一応の解決を見た。しかし， 重回帰分析の場合はどうであるかはまだ検討されてい ない.

\section{2 空間的自己相関}

空間的自己相関 (spatial autocorrelation) ${ }^{4)}$ の問題は 地域事象の回帰分析に括けるもっとも重要な問題の一つ である (Tobler (1966) や Curry (1966))。この種の相 関は, $S$ 行 $R$ 列の方格から成る地域を想定するとき, その地域の任意の方格 $h$ に和ける变数 $x_{h}$ をその方格の 位置を示す座標 $(i, j)$ で表現した場合の变数 $x_{i j}$ が, 次式で示されることをいう。

$$
\begin{array}{r}
x_{i j}=a x_{i-1, j}+b x_{i+1, j}+c x_{i, j-1}+d x_{i, j+1}+\varepsilon_{i j} \quad(3.2) \\
\text { (ただし, } i=1, \cdots, S ; j=1, \cdots R)
\end{array}
$$

計量経済学において問題とされる時系列の第 1 階自己相 関モデル $x_{i}=\rho x_{t-1}+\varepsilon i$ と異なる点は, いうまでもなく 空間的自己相関モデルが 2 次元的なるのであること，拉 よび系列事象に方向性があることである。このような相 関の測度と検定法が導出されている.

これらは最初, 方格の持つ変数の 2 次元的な隣接性 (contiguity) の問題として Moran (1950) によって提唱 されたものである.彼は次のような隣接性統計量 I を提 示した.

$$
\begin{gathered}
I=\left(\frac{1}{2} \sum_{h=1}^{N} \sum_{l=1}^{N} \delta_{h l} z_{h} z_{l}\right) / \sum_{h=1}^{N} z_{h}{ }^{2} \\
\text { ここでの } N=R S, \quad z_{h}=x_{h}-\bar{x}, \quad z_{l}=x_{l}-\bar{x} \quad\left(x_{l}\right. \text { は座標 } \\
(f, g) \text { を持つ方格 } l \text { の变数), } \delta h l \text { (ただし } h \neq l) \text { は方 }
\end{gathered}
$$

4）ここでは同一種類の変数間の相関を自己相関と呼 ふ. 
格 $h$ と方格 $l$ が隣接している場合は 1 , 非隣接の場合は 0 となるダミ一変数的な指標. 次にこの統計量を Geary (1954) が追跡して, 式（3.3）の分子を若干変形した (変数の平均から 偏差 $z$ によずに原変数值 $x$ を用い る) 隣接性統計量 $C$ と, 変数が平均 1 .未知分散 $\sigma^{2}$ を 持つ正規母集団からの標本であると仮定することによっ て, この統計量についての原点のまわりの積率とを誘導 した。隣接性統計量としては,

$$
C=\left[(N-1) \sum_{h=1}^{N} \sum_{l=1}^{N} \delta_{h l}\left(x_{h}-x_{l}\right)^{2}\right] / 4 A \sum_{h=1}^{N} z_{h}^{2}
$$

ここでの $A=\frac{1}{2} \sum_{h=1}^{N} \sum_{l=1}^{N} \delta_{h l} . C$ の 1 次積率と 2 次積率 はそれぞれ，

$\mu_{1}^{\prime}=1$

$\mu_{2}^{\prime}=\left[N^{2} k_{1}{ }^{2}+2 N\left(k_{1}+k_{2}\right)\right]\left[(N-1) / N^{2}(N+1) k_{1}{ }^{2}\right]$

ここでの $k_{1}=2 A / N, k_{2}=\left(\sum_{h=1}^{N} \sum_{l=1}^{N} \delta_{h l}\right) / N$. そして,

これらにもとついて $C$ の有意性を調べるために次のよ らな検定統計量（標準正規変量）を見出した。

$$
R=(1-C) /\left(\mu_{2}^{\prime}\right)^{1 / 2}
$$

このような $I$ および $C$ は, いくつかの方格の隣接・非 隣接のみを表現する隣接性指標 $\delta h l$ を含んでいるだけ で, 方格間の隣接度合の強弱や方格の面積などを無視し ている限定的な統計量といえる (Dacey (1968))．とこ で, Cliff \& Ord (1970) はこの欠点を補らこころみと して次のよらな一般化 Geary 係数 $C^{\prime}$ とそれに関する 1 次と 2 次の積率とを誘導した。

$$
\begin{aligned}
C^{\prime}= & {[(N-1) / 2 W]\left[\sum_{h=1}^{N} \sum_{l=1}^{N} w_{h l}\left(x_{h}-x_{l}\right)^{2}\right] } \\
& / \sum_{h=1}^{N} z_{h^{2}}
\end{aligned}
$$

そして

$$
\begin{aligned}
& \mu_{1}^{\prime}=1 \\
& \mu_{2}^{\prime}=\left[\left(2 S_{1}+S_{2}\right)(N-1)-4 W^{2}\right] /\left[2(N+1) W^{2}\right]
\end{aligned}
$$

ここでの $w_{h l}$ は何らかの基準によって $\delta_{h l}$ に加重したも の, $W=\sum_{h=1}^{N} \sum_{l=1}^{N} w_{h l}, S_{1}=\frac{1}{2} \sum_{h=1}^{N} \sum_{l=1}^{N}\left(w_{h l}+w_{l h}\right)^{2}, S_{2}=$ $\sum_{h=1}^{N}\left(w_{h} \cdot w_{h}\right)^{2}$

地域事象の共变動の研究において回帰分析が頻用され
ていると前述したが，空間自己相関の問題は回帰論との 関連において重要な意味を持っている，線形回帰モデル $Y_{h}=\alpha+\beta X_{h}+\varepsilon h$ に拉いて残差 $\varepsilon_{h}$ の独立性执よび正規 性が前提とされているが，地域事象の回帰分析の諸研究 を見るとほとんどのものがこれらの前提を満たしていな い.とりわけ，前者の前提に対して社会・経済的データ は現実的に空間的自己相関を持つ場合がきわめて多いに もかかわらず，残差についての自己相関の有無つまり独 立性の検定を行っていない. 計量経済学にあっては周知 のダービン・ワトソン比によるその種の検定がなされ， 残差に自己相関の存在する場合に回帰パラメータの最 良不偏推定值を与える一般化最小 2 乗法が, Johnston (1963) によって提起されている. 時系列データの分析 についてのダービン・ワトソン比に相当する空間系列で の統計量が, 上述した諸隣接性統計量であるので, 地域 事象のデータにもとづく回帰方程式が独立性, 換言すれ ば空間的無自己相関性の前提を満たしているか否かはそ れらによって検定できる。しかし，その検定の結果とし て，残差に空間的自己相関が見られたとする場合，どの ような方法で最良不偏推定值を得ればいいかが新たな問 題となる. 空間的自己相関の場合では，一般化最小 2 乗 法に相当するものがないのである．この 2 乗法の骨子と なっている残差の自己相関構造に対応する空間的な残差 の自己相関構造の探索に Matern (1960) の研究が一つ の示唆を与えるかもしれない。なお，空間的回㷌論に拉 ける残差の正規性に関する検定統計量をる Cliff \& Ord が導出している.

\section{3 地域構成分析}

多变量解析法のらち主成分分析および因子分析は地域 事象の共変動の基本的次元の抽出に有用であり, 心理学 や教育学が人間の基本的性格を探索するのにそれらの手 法を適用するのと同じ立場で, 地域の基本的性質（諸事 象が共変動している状態そのものに他ならない）や地域 の構成要素としての諸事象の解明に利用され, 多くの成 果を挙げている.このような利用は一層拡大され, 地理 学にお汗る基本的な地域概念と結合して地域構成分析 (regionalization) が行われるようになった. 一般に地域 とは単なる形状と面積を有するだけの物理的空間を意味 するのではなく, 相互に関連した諸事象の充填した小単 位空間（地区）の集合体を指す，その諸事象の類似性に もとづく集合体を等質 (homogeneous) 地域, 諸事象の 結合性にもとづくそれ機能 (functional) 地域という. したがって，これらの地域は多数の地区の類似性または 結合性の度合による階層的な合成体つまり階層構造とし 


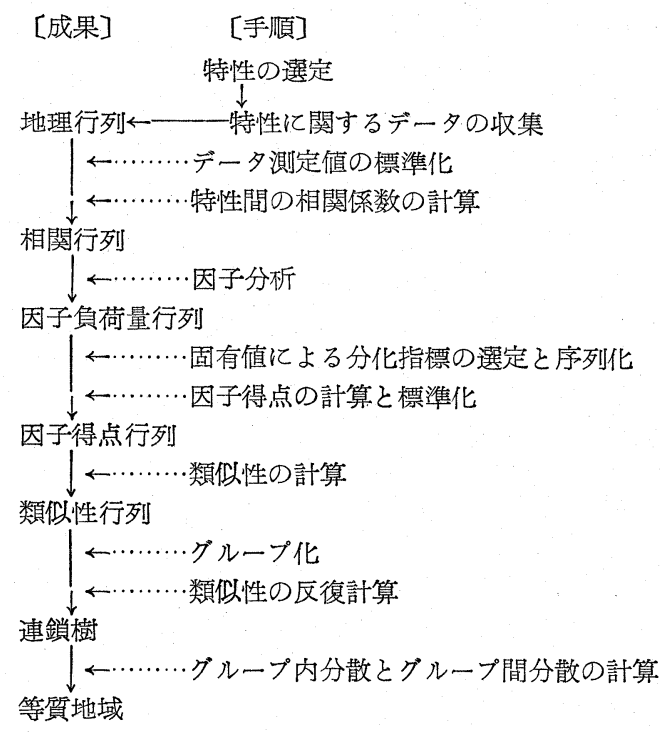

図4 等質地域画定の操作

て認識されよう。しかし, 各地区はきわわて多くの事象 を含み，他地区とどの程度頪似または結合しているのか を総合的かつ客観的に判定することはきわめてむずかし い. そこで, 多数の事象の中から重要なものだけを抽出 し, 地区ごとのその類似性または結合性を計測すること によってこの問題を解決しょうとするこころみが始めら れた。これが地域構成分析であり，その端緒となったの は Berry（1961）によるアメリカについての等質地域的 な考察である.

各地区についての類似性に着目する地域構成分析のア プローチは図 4 のような手順をともなら.この操作手順 において重要な機能を果たすのは因子分析であり，これ は対象地域においてその性質を規定する基本的次元つま りは類似性を計測すべき重要な諸指標を提供するととも に, それらによる直交空間へ各地区を写像して, 頑似性 の計測を容易にさせる.したがって，通常の因子分析に あっては因子負荷量が重視されるのに対して, ここでは 因子得点が重視されるのである. 因子得点にもとづく類 似性の測度としては次式に示されるユークリッド平方距 離 $D_{A B^{2}}$ が一般的である.

$$
D_{A B^{2}}=\sum_{i=1}^{m}\left(x_{A i}-x_{B i}\right)^{2}
$$

ここでの $m$ は因子数， $x_{i A}$ と $x_{i A}$ は地区 $A$ と $B$ そ れぞれに打ける因子 $\boldsymbol{i}$ の得点. 地区数を $N$ とし, 各地 区間の平方距離を $N$ 次の類似性行列として表示する. そこで最小平方距離を有する 2 地区をグループ化し，そ
のグループの代表点の座標とその点から他の諸地区まで の平方距離を算定して, 新たな $(N-1)$ 行 $(N-1)$ 列 の類似性行列学作成し，そしてその行列での最小平方距 離を識別する，同様の操作を反復し（グループ化の対象 地区またはグループはつねに二つであることから連鎖法 (linkage analysis) といわれる), 最終的に等質地域を決 定するのである。ここで問題となるのは任意の反復段階 で設定されたグループの代表点として何を取るか，また 最適グループ化の判定基準を何に求めるかである，前者 については平均点・重心点・最近隣点・最遠隣点などが 提唱されている. Berry による等質地域設定では平均点 が取り上げられているが，Lankford（1969）によると， 平均点の場合はそれによってもたらされる真の代表点と の刋離——連鎖効果といわれる—が最大となるとされ ている，後者については, グループ間分散のグループ内 分散に対する比を最大化する段階が，最適グループ化の 段階であることはいらまでるないが，これは明らかに前 者の問題と関連している. 重心点をグループ代表点とし た場合は，各段階におけるグループ間平方距離和のグル 一プ内平方距離和に対する比が判定基準として有效であ ると Berry (1967) によって提唱され，それを最大化す る段階が最適段階であるとされている。いずれにしても これらの問題の決定的な解はまだ見出されていない，奥 野・鈴木（1973）が名古屋地域に叔ける等質地域画定の さいに用いた判定基準 $C_{d}$ は次のようなものであり， 294 地区のグループ化に和いて 242 段階目で最適グループ化 が達成された。

$$
C_{d}=\left(\sum_{k=1}^{s} \sum_{j=1}^{r} d_{k j}^{2}\right) / \sum_{j=1}^{N} D_{j}^{2}
$$

ここでの $d_{k j}{ }^{2}$ はグループkにおけ地区 $j$ からそのグ ループの重心点までの平方距離 $\left(=\sum_{i=1}^{m}\left(x_{i k j}-x_{i k g}\right)^{2}\right)$ $s$ は任意の段階で存在するグループ数, $r$ はそのグルー プを構成する地区数, $D^{2}$ は最終段階におけるグループ の重心点から地区 $j$ までの平方距離, $x_{i k j}$ はグループk の地区 $j$ についての因子 $i$ の得点， $x_{i k g}$ はそのグルー プの重心点の座標.

機能地域の画定は，等質地域のそれが行に諸事象，列 に地区を取ったデータ行列について, 諸事象を示す変数 間の相関を重視する $R$ 技法の因子分析を行らことから 出発するのに対して，地区間の結合を表現する流動事象 一例えば電話通話や自動車交通——ついての着地之 発地を行と列に取る流動データ行列への同様な因子分析 の適用によって可能である，因子負荷量行列は着地パタ 
ーンを, 因子得点行列は発地パターンを示し，両パター ンを組み合わせることによって機能的な中心地とその後 背地が判明する．この種の経験的研究としては Illeris

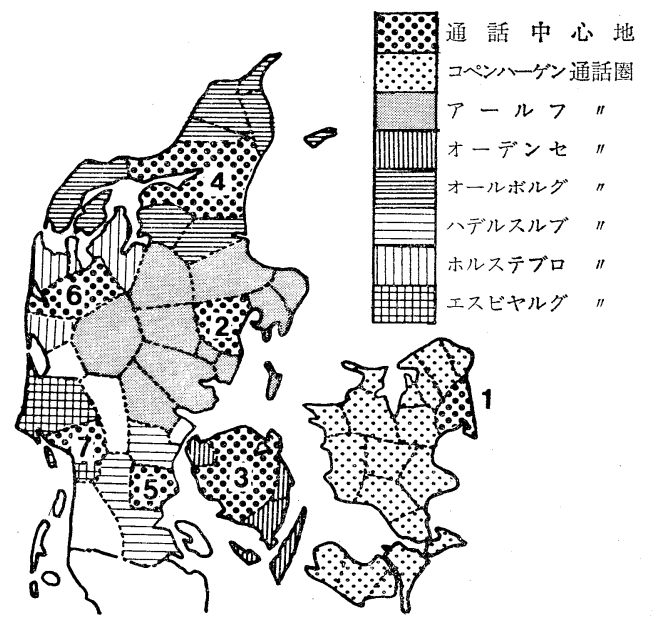

四 5 デンマークの通話圈 (Illeris \& Pedersen)
1. コペンハーダン
2. アールフ
3. オーデンセ
4. オールボルグ
5. ハデルスルブ
6. ホルステブロ
7. エスビヤルグこの番号は中心地の重要度 の順位による。

\& Pedersen (1968) が挙げられる. 彼らはデンマーク の電話通話データについての因子分析から図 5 のよらな 機能地域を画定し，そして中心地として抽出された 7 都 市の重要性が，因子の固有値に上る場合と他の指標に上 る場合と注汸一致することを見出し，機能地域画定にさ いしての因子分析の有用性を例証した.

こうした機能地域は因子分析以外の手法にょっても 見出されることはいうまでもない.グラフ理諭による Neystuen \& Dacey（1961） やマルコフ連鎖による接近 をこころみている Brown \& Holmes (1971) などが注 目されよう。

\section{あとがき}

ここでは点的な地域事象の分布パターン分析および地 域事象の共変動に関しての諸問題を述べたが, その他に 線的な地域事象一ネットワーク一の構造分析や設計 に打ける問題, 地域事象の 2 次元的分布の一般性を見出 す傾向面分析, その事象の時間に上る拡散過程の分析な ぞ興味深いものがある，紙面の関係でそれらは割愛せざ
るを得ない、それらについては別の機会に譲りたい（そ の一部については恐らく本誌の石水論文で言及されてい ると思われる).

\section{参考文 献}

Anscomb, F.J. (1950) Sampling theory of the negative binomial and logarithmic series distributions. Biometrika, 37, 358-382.

Bachi, R. (1963) Standard distance measures and related methods for spatial analysis. Papers, the Regional Science Association, 10, 83-132.

Berry, B.J.L. (1961) A method for deriving multi-factor umiform regions. Przeglad Geograficzny, 33, 263-282.

Berry, B.J.L. (1967) Grouping and regionalizaing; an approach to the problem using multivariate analysis. In W.L. Garrison \& D.F. Marble (Eds.) Quantitative geography Part I. Studies in geography, 13, Northwestern Univ., 219-251.

Brown, L.A. \& Holmes, J. (1971) The delimitation of functional regions, nodal regions, and hierarchies by functional distance approaches. J. of Regional Science, 11, 1, 57-71.

Clark, P.J. \& Evans, F.C. (1954) Distance to nearest neighbor as a measure of spatial relationships in populations. Ecology, 35, 445453.

Cliff, A.D. \& Ord, K. (1970) Spatial autocorrelation; a review of existing and new measures with applciations. Econ. Geog. 46, 2 (Supplement), 269-292.

Curry, L. (1966) A note on spatial association. Professional Geographer, 18, 97-99.

Dacey, M.F. (1963) Order neighbor statistics for a class of random patterns in nultidimensional space. A.A.A.G., 53, 505-515.

Dacey, M.F. (1964a) Modified Poisson probability law for point pattern more regular than random. A.A.A.G., 54, 559-565.

Dacey, M.F. (1964b) Two-dimensional random point patterns; a review and an interpretation. Papers, the Regional Science Association, 13, 41-55.

Dacey, M.F. (1965a) Measures of distance from a randomly located point to neighboring lattice points for rectangular and hexagonal point lattices. Dept of Geog., Northwestern Univ.

Dacey, M.F. (1965b) Numerical measures of random sets. Dept. of Geog., Northwestern 
Univ.

Dacey, M.F. (1965c) Four properties of twodimensional random point pattern. Dept. of Geog., Northwestern Univ.

Dacey, M.F. (1966a) A compound probability law for a more dispersed than random and with areal inhomogeneity. Econ Geog., 42, 172-179.

Dacey, M.F. (1966b) A county-seat model of the areal pattern of an urban system. Geog. Rev., 56, 527-542.

Dacey, M.F. (1968) A review on measures of contiguity for two and $\mathbf{k}$-color maps. In B.J.L. Berry \& D.F. Marble (Eds) Spatial analysis; a reader in statistical geography. Prentice-Hall, 479-495.

Geary R.C. (1954) The contiguity ratio and spatial mapping. Incorporated Statistician, 5, 115-141.

Hayford, J.F. (1902) What is the center of an area, or the center of a population. $J$. of the Amer. Statistical Association, 8, 47-58.

Illeris, S. \& Pedersen, P.O. (1968) Central places and functional regions in Denmark factor analysis of telephone traffic. Lund studies in geography, Ser. B, 31, C.W.K. Gleerups.

Johnston, J. (1963) Econometric methods. McGraw-Hill.

Jones, W.D. (1930) Ratios and isopleth maps in regional investigation of agricultural land occupance. A.A.A.G., 20, 177-195.

Kendall, M.G. (1939) The geographical distribution of crop productivity in England. $J$. of Royal Statistical Society, 102, 21-48.

久野英二 (1974) 生物個体群の 分布様式 I. 分布型の 一般モデル．応用統計学， 4, 39-54.

Lankford, P.M. (1969) Regionalization; theory and alternative algorithms. Geog. Analysis, 1, 196-212.

Matern, B. (1960) Spatial variation. Meddelanden Fran Statens Skogsforskningsinstitut,
49, 1-144.

McCarty, H.H. et al. (1956) The measurement of association in industrial geography. Dept. of Geog., Univ. of Iowa.

Moran, P.A.P. (1950) Notes on continuous stochastic phenomena. Biometrika, 37, 17-23.

Neft, D. (1966) Statistical analysis for areal distributions. Monograph Ser., 2, Regional Science Research Institute.

Neystuen, J.D. \& Dacey, M.F. (1961) A graph theory interpretation of nodal regions. Papers and Proc., the Regional Science Association, 7, 29-42.

奥野隆史・鈴木栄一（1973）定量的地域区分法とその 適用. 青山経済論集, 24-3, 39-63.

Porter, P.W. (1963) What is the point of minimum aggregate travel ? A.A.A.G., 53, 224232.

Robinson, A.H. (1956) The necessity of weight -ing values in correlation of areal data. A.A.A.G., 46, 233-236.

Robinson, A. H. et al. (1961) A ccorelation and regression analysis applied to rural farm population densities in the Great Plains. A.A.A.G., 51, 211-221.

Seymour, D. (1965) IBM 7090 program for locating bivariate means and bivariate medians. Dept. of Geog., Northwestern Univ.

Thomas, E.N. and Anderson, D.L. (1965) Additional comments on weighting values in correlation analysis of areal data. A.A.A.G., 55, 492-505.

Tobler, W.R. (1966) Numerical map generalization and notes on the analysis of geographical distributions. Mich. Inter-Univ. Commu. of Math. Geog. Discussion Paper, 8, Univ. of Michigan.

Williamson, E. \& Bretherton, M.H. (1963) Tables of the negative binomial probability distribution. John Wiley \& Sons.

Yule, G.U. \& Kendall, M.G. (1950) An introduction to the theory of statistics. Hafner. 